\title{
ICT Use in Science and Mathematics Teacher Education in Tanzania: Developing Technological Pedagogical Content Knowledge
}

\author{
Ayoub Kafyulilo \\ Dar es Salaam University College of Education, Tanzania \\ Petra Fisser \\ National Institute for Curriculum Development, The Netherlands \\ Jules Pieters \\ University of Twente, The Netherlands \\ Joke Voogt \\ University of Amsterdam/Windesheim University, The Netherlands
}

\begin{abstract}
Currently, teacher education colleges in Tanzania are being equipped with computers to prepare teachers who can integrate technology in teaching. Despite these efforts, teachers are not embracing the use of technology in their teaching. This study adopted Technological Pedagogical Content Knowledge (TPACK) as a framework for describing the knowledge and skills that pre-service teachers need to develop in order to effectively integrate technology in science and mathematics teaching. Pre-service teachers $(\mathrm{N}=22)$ participated in microteaching, hands-on training, collaborative lesson design in design teams, and reflection with peers. Preand post-assessment results of the pre-service teachers' perceived knowledge and skills of integrating technology in teaching, showed significant changes in technology-related components of TPACK. We conclude that opportunities for pre-service teachers to participate in professional development programs that involve lesson design, teaching, evaluation and redesign, can be effective for the development of the knowledge and skills of integrating technology in science and mathematics teaching.
\end{abstract}

\section{Introduction}

Tanzania experiences, just like many developed and developing countries, a challenge in relation to students' participation and performance in science and mathematics subjects at secondary school education. A report by the Mathematical Association of Tanzania (MAT) shows that from 2003 to 2007 the failure rates in Basic Mathematics among secondary school students reached 73\% (United Republic of Tanzania [URT], 2008). According to the National Examination Council of Tanzania examination cycle for 2002 - 2008, failure rates in physics and biology from 2002 to 2007 were between 40-46\% in physics and between 45-76\% in biology. These failures have been attributed to, amongst other factors, the absence of competent teachers, lack of science teaching and learning resources as well as shortage of science and mathematics teachers in most schools (URT, 2008).

Since the 1990s the government of Tanzania has taken several initiatives to address the problem of massive failures in science and mathematics subjects in the country. Several projects were established in collaboration with international organisations to enhance science and mathematics teaching approaches, to prepare new teaching resources including books, and training of more science and mathematics teachers (O-saki, 2007). One of the projects was the Science Education in Secondary Schools (SESS) a project funded by the German GTZ in 1997, and based in the Ministry of Education and Culture in Tanzania, aiming at improving teaching and learning in science and mathematics for girls and boys in secondary schools (O-level) in Tanzania. Another project was the Teacher Education in Mathematics and Science (TEAMS) from 1996 to 2004 which was funded by the Dutch government to review the undergraduate science teacher education programs at the University of Dar es Salaam, by conducting research, training postgraduate students and developing in-service 
training materials (Ottevanger, van den Akker, \& de Feiter, 2007). Despite these initiatives to overcome the massive failure of students in science and mathematics, the situation has remained poor (O-saki, 2007).

Further efforts to enhance science and mathematics teaching and learning outcomes focused on the introduction of ICT in education. Thus, in 2002 the government of Tanzania in collaboration with the Swedish International Development Agency (SIDA) and the International Institute for Communications Development (IICD), a Dutch NGO, started to implement ICT for science, mathematics and English subjects in both teacher education and in secondary schools (Hare, 2007; Tilya, 2008). From this period the Ministry of Education and Vocational Training (MoEVT) endorsed that ICT should not only be taught as a subject, but also be integrated as a pedagogical tool for teaching and learning in subject areas (URT, 2007). Despite the fact that the government of Tanzania introduced the use of technology in education as of 2002, the ICT uptake by teachers is still low and improper (Hare, 2007; Ottevanger et al, 2007). Several studies (Hare, 2007; Swarts \& Wachira, 2010; Tilya, 2007) revealed that the computers that are available in schools in Tanzania are mostly used for administration purposes, and sometimes for teaching basic ICT skills, but not as tools for instructional delivery. According to Swarts and Wachira (2010) the low uptake of technology by teachers is caused by the limited knowledge and skills of teachers on technology integration in teaching. Therefore the aim of this study is to develop and evaluate a professional development programme for pre-service teachers to effectively incorporate ICT in their teaching when they commence employment.

\section{ICT policies and implementation in schools and teacher education in Tanzania}

The first national ICT policy in Tanzania was developed in 2003. This policy had two main objectives: (1) to provide a national framework to enable ICT to contribute towards achieving national development goals; and (2) to transform Tanzania into a knowledge-based society through the application of ICT (URT, 2003). The 2003 ICT policy did not specifically focus on the ICT development in education, and had no relationship with the earlier initiatives to integrate technology in education. Rather, it focused on guiding the overall use of ICT in the country, including mobile phones, computer, internet and other related ICT tools, be it in schools, in offices or at the market. According to Tilya (2008) the 2003 policy can be described as an emerging policy in education, where ICT is just in the process of being introduced into schools. In 2007 the ICT Policy for Basic Education was formulated. It aimed to promote the acquisition and appropriate use of literary, social, scientific, vocational, technological, professional and other forms of knowledge, skills and understanding for the development and improvement of man and society (URT, 2007). This policy incorporates the integration of ICT in pre-primary, primary, secondary and teacher education, as well as non-formal and adult education (Hare, 2007; URT, 2007). Such a policy, according to Tilya (2008) could be described as an applying policy, which refers to teachers' use of ICT for both administration and instruction purposes.

The ICT, 2003 and 2007, policies are implemented in collaboration with other education development policies governing the education sector in Tanzania. These are; the Education and Training Policy of 1995, the Primary Education and Development Plan (PEDP) 2002-2006, and the Secondary Education Development Plan (SEDP) 2004-2009 (URT, 2009). PEDP and SEDP prioritise ICT-based information management at all levels and an introduction of computer courses into primary and secondary education (Hare, 2007; URT, 2009). The expansion of primary education enrolment through the PEDP (2002- 2006) and the creation of new secondary schools through the SEDP (2004 -2009) created an enhanced demand for graduate teachers and tutors in the country. This led to the establishment of the Dar es Salaam University College of Education (DUCE) in 2005 with the aim to combat the acute shortage of teachers in secondary schools and to integrate technology in education. In relation to the latter, DUCE offers three ICT related courses to pre-service science and mathematics teachers: Computer Literacy for Teachers (3 units), Educational Media and Technology (3 units), and ICT in Science and Mathematics Education (3 units). Computer Literacy for Teachers is an introductory course which is taken by all first year students joining in the teacher education at the college. It aims at developing the basic ICT knowledge and skills to teachers. On the other hand, the Educational Media and Technology course covers a wide range of technological tools such as biological models and scientific charts, for example periodical table and digital technological tools such as mobile phones, computers, radios 
etc. This course is offered to all second year student teachers at the college. Finally the ICT for Science and Mathematics course is offered to second year science and mathematics student teachers only.

Although there is evidence that pre-service teachers are prepared to use technology in their teaching, studies (Hare, 2007; Vesisenaho, 2007) report poor technology integration in schools. Even though teachers are learning to use and integrate technology into their teaching, teachers are not using technology as a pedagogical tool to enhance teaching and learning in their subjects. Studies (Hare, 2007; Ottevanger et al, 2007; Vesisenaho, 2007) report that ICT use in schools in Tanzania is mostly confined to management and administration purposes. According to Hare (2007) in most of the schools ICT is used for keeping students' records and typing office documents such as letters. Swarts and Wachira (2010) indicated that although teachers have the basic knowledge of ICT, many of them do not know how ICT is integrated in teaching. The limited use of technology for instruction is what prompted this study to introduce the professional development program to develop pre-service teachers' knowledge and skills of integrating technology in science and mathematics teaching. Technological Pedagogical Content Knowledge (TPACK) was adopted as an effective framework for developing pre-service teachers' knowledge and skills of integrating technology in teaching (cf. Agyei \& Voogt, 2012; Alayyar, Fisser, \& Voogt, 2012). The motives behind the study of technology integration at college level emerged from the findings from Dudink and Berge (2006) and Fullan (2007) who call for a balance between top-down and bottom-up approaches to educational innovations. Additionally, the priority for ICT deployment by the Ministry of Education and Vocational Training in Tanzania has been in the teacher training colleges (Swarts \& Wachira, 2010).

In 2009, the government of Tanzania developed the Information and Communication Technology for Teacher Professional Development (ICT-TPD) as an implementation of the ICT for basic education policy and the Education Sectoral Plans and programmes. ICT-TPD aimed at developing teachers' capacity of integrating technology in science, mathematics and English subjects in Tanzania secondary schools (URT, 2009). The government of Tanzania consulted the Global e-school and Community Initiative (GESCI) to implement ICTTPD through the ICT for Science, Mathematics and English (ICT-SMEs) project, which adopted the Technological Pedagogical Content Knowledge (TPACK) framework (Swarts \& Wachira, 2010).

\section{Developing Teachers' knowledge and skills of integrating technology in teaching}

According to Mishra and Koehler (2006) at the heart of good teaching, there are three components; content, pedagogy and technology, plus the relationship among and between them which makes up TPACK. TPACK comprises of seven components among which, three are the core components namely technological knowledge (TK), pedagogical knowledge (PK), and content knowledge (CK). The interaction between these three, results in technological pedagogical knowledge (TPK), technological content knowledge (TCK), pedagogical content knowledge (PCK), and technological pedagogical content knowledge (TPCK). These seven components are enclosed together to form a Total PACKage of technological pedagogical content knowledge (TPACK) (Thompson \& Mishra, 2007-2008). In 2008 Koehler and Mishra (2008) added context to the framework, as context determines to a large extent the way technology can be used in educational practice. Although most studies on TPACK seem to ignore context in the way TPACK can be used and understood in practice (Koh, Chai, \& Tay, 2014), it makes the framework relevant for many different contexts. The study of Agyei and Voogt (2012) for instance showed that access to hard and software in a country such as Ghana is scarce and classes usually large. They therefore decided to introduce pre-service mathematics teachers to spreadsheets, commonly available software. Pre-service teachers designed mathematics lessons in which spreadsheets were integrated using an activity-based approach to learning that suited large classrooms.

TPACK has been welcomed as a framework to guide research on teacher learning about the integration of technology in the classroom, not only in the USA, but worldwide. For instance TPACK has been adopted in Kuwait (Alayyar et al., 2012), in Greece (Jimoyiannis, 2010), Taiwan (Lee \& Chai, 2010) and Hong Kong (Law, Yuen, \& Lee, 2014), Singapore (Koh, Chai, \& Tay, 2014) and also in Africa. In Africa, TPACK has 
been used in Ghana (Agyei \& Voogt, 2012) and Tanzania (Kafyulilo, Fisser, \& Voogt, 2014) as a framework for pre-service teachers' professional development to integrate technology in mathematics and science teaching respectively.

However despite the extensive use of and research on TPACK, TPACK as a theoretical construct is not yet very well understood and this probably has its influence on measuring TPACK development too (Voogt, Fisser, Pareja Roblin, Tondeur, \& van Braak, 2013). The discussion about TPACK as a theoretical construct focuses on either the difference between TPACK (including all seven knowledge domains) or TPCK (the core of the framework). The measurement discussion is not only about different ways to operationalise TPACK in self-assessment survey instruments; it is also about the use of self-assessment instruments to measure TPACK instead of observable measures of knowledge and skills (Voogt et al., 2013). Notwithstanding these scholarly discussions, it is generally acknowledged that interaction between content, pedagogy and technology are important in the development of teachers' knowledge and skills to integrate ICT use in their teaching. According to Tondeur, Pareja Roblin, van Braak, Fisser and Voogt (2012) TPACK can be used as a framework in preparing teachers to make deliberate choices in using technology in educational practice. For this reason and because the TPACK framework speaks to teachers and policymakers, we adopted TPACK in this study as a framework for describing the knowledge base that pre-service teachers need to develop in order to integrate technology in science and mathematics teaching in Tanzania.

To develop pre-service teachers' TPACK, learning technology by design is advocated as a promising approach (e.g. Agyei \& Voogt, 2012; Alayyar et al., 2012; Angeli \& Valanides, 2009; Koehler, Mishra, \& Yahya, 2007; Mishra \& Koehler, 2006). Key in this approach is the collaborative design of technologyenhanced lessons (or lesson activities) by (pre-service) teachers. Collaborative design by teachers complies with current notions on effective professional development (Voogt et al., 2011). Based on an analysis of qualitative studies on pre-service teacher preparation for technology use in educational practice, Tondeur et al. (2012) found six elements foster pre-service teachers' learning on why and how to integrate technology in classroom practice, so to develop pre-service teachers' TPACK. These elements are; (1) aligning theory to practice, (2) teacher educators as role models. (3) reflection on the role of technology in education, (4) design of technology-enhanced lessons, (5) collaboration with peers, and (6) scaffolding authentic technology opportunities. In collaborative design in teams these elements can be implemented when the learning process around the design activities of the teams is carefully structured. Peker (2009) proposes an approach, in which pre-service teachers engage in the design of the lesson, teach to peers through microteaching, discuss with peers the outcomes of teaching, and re-design the lesson. Similarly, Jimoyiannis (2010) adopted an approach which involved the planning, development, evaluating and revisiting. According to Kilic (2010) and Peker (2009) the process whereby, pre-service teachers design a lesson, present to peers through microteaching and reflect on it, is effective for teachers' professional development because it exposes them to the challenges of an actual classroom teaching. Jimoyiannis (2010) acknowledges this approach for enabling pre-service teachers to develop skills of drawing attention, asking questions, using and managing time effectively and bringing the lesson to a conclusion.

\section{The professional development arrangement}

This study adopted the plan, teach, evaluate, re-plan approach as proposed by Peker (2009). This approach is described by Jimoyiannis (2010) as a planning, development, evaluation, rethinking approach. In this study we followed the four stages through: lesson design (planning), microteaching (teaching), peer reflection (evaluation) and lesson re-design (re-plan). Before engaging in the intervention, pre-service teachers' technology integration knowledge and skills were assessed. In the first meeting, pre-service teachers were asked to form four teams of 5 to 6 people and prepare a technology integrated lesson by using their own experiences. One person from each group taught the designed lesson to peers (microteaching). After the microteaching there was a peer reflection to evaluate the taught lesson. The resulting outcomes of the reflection and observation were the basis for the design of the professional development arrangement, consisting of a 2 day workshop to introduce the concept of TPACK. This was followed by the lesson (re)design which took about 3 weeks. The newly (re)designed lessons were taught to peers through microteaching and reflected upon by peers. 


\section{Research questions}

In this study we introduced a professional development program for pre-service teachers that involved lesson design, microteaching, reflection and lesson re-design. Our main research question was:

What was the effect of the professional development arrangement on the development of knowledge and skills of integrating technology in science and mathematics among the pre-service teachers?

This question was answered by dividing it into three sub questions:

1. What was the pre-service teachers' perceived TPACK before and after the professional development arrangement?

2. What were the observed pre-service teachers' practices with technology-enhanced science and mathematics teaching before and after the professional development arrangement?

3. What activities within the professional development arrangement were perceived by the pre-service teachers as effective for developing their TPACK?

\section{Methodology}

Based on studies conducted in similar contexts, one by Agyei (2012) in Ghana and one by Alayyar (2011) in Kuwait, the concept of collaborative design in teams was applied to pre-service teacher training in Tanzania. A context-based professional development arrangement was designed, whereby pre-service teachers participated in a workshop, collaborated in teams to design technology-enhanced science and mathematics lessons, taught the designed lessons to peers through microteaching, and reflected upon the lessons with peers.

\section{Participants}

A total of 22 pre-service science and mathematics teachers in the Bachelor of Education in Science [B.Ed (science)] from DUCE participated in the study. The participants were selected purposefully, because by the time this study was conducted, they were in the last month of their bachelors' program and were expected to demonstrate an exemplary competence level that pre-service teachers acquire at DUCE. Also the B.Ed (science) program included students who specialised in mathematics, chemistry, physics and biology, and attended a course on ICT for science and mathematics teachers; which were the focus subjects in this study (i.e. science, mathematics and ICT).

\section{Instruments}

Three kinds of data collection instruments were used in this study: the TPACK survey, an observation checklist and a reflection questionnaire. Two instruments, the TPACK survey and the observation instrument, measure TPACK development. In this way we were able to triangulate findings and to some extent compensate for weaknesses of each individual instrument (Voogt et al., 2013). The entire data analysis was quantitative. Although observation is qualitative in its nature, the use of checklist makes it possible to transform data from qualitative to quantitative data. However, to offer an opportunity for pre-service teachers to express their feelings, the reflection questionnaire provided open-ended questions to allow for pre-service teachers' self-expression.

The three instruments were used to establish the pre-service teachers' perception on their knowledge and skills of integrating technology in teaching, and the actual (observable) knowledge they were able to demonstrate in practice. An overview of the instruments and the research questions they aimed to answer is presented in Table 1. 
Table 1

Overview of data collection instruments and research questions

\begin{tabular}{lccc}
\hline \multirow{2}{*}{ Data Collection Instruments } & \multicolumn{3}{c}{ Research Questions } \\
\cline { 2 - 4 } & RQ1 & RQ2 & RQ3 \\
\hline TPACK survey & $\sqrt{ }$ & $\sqrt{ }$ \\
Observation checklist & & & $\sqrt{ }$ \\
Reflection survey & & & \\
\hline
\end{tabular}

TPACK survey

The TPACK survey intended to gather data on pre-service teachers' perceived knowledge and skills of integrating technology in science and mathematics teaching before and after the intervention. The instrument was adopted from Schmidt et al (2009) and uses a 5-point Likert scale: 1 = strongly disagree, 2 = disagree, 3 = neutral, 4 = agree, 5 = strongly agree (see Appendix A). The TPACK survey and its reliability in Cronbach's alpha are summarised in Table 2.

Table 2

Summary of the TPACK survey instrument

\begin{tabular}{llcc}
\hline \multirow{2}{*}{ Construct } & \multicolumn{1}{c}{ Exemplary item } & $\begin{array}{c}\text { No. of } \\
\text { items }\end{array}$ & $\begin{array}{c}\text { Cronbach's } \\
\boldsymbol{\alpha}\end{array}$ \\
\hline TK & I can use technology without problems & 7 & 0.77 \\
PK & I can adapt my teaching style to different learners & 7 & 0.84 \\
Math K & I have sufficient knowledge about Mathematics & 4 & 0.81 \\
Physics K & I have sufficient knowledge about Physics & 4 & 0.82 \\
Biology K & I have sufficient knowledge about Biology \\
PCK & $\begin{array}{l}\text { I can easily select the suitable teaching approach for a given } \\
\text { topic. }\end{array}$ & 4 & 0.92 \\
TCK & $\begin{array}{l}\text { I can choose technology that enhances content for a lesson I } \\
\text { teach }\end{array}$ & 3 & 0.71 \\
TPK & $\begin{array}{l}\text { I am thinking critically on how I can use technology in } \\
\text { teaching }\end{array}$ & 4 & 0.85 \\
TPCK & $\begin{array}{l}\text { I can teach a lesson that combine science, technology and } \\
\text { teaching approaches }\end{array}$ & 4 & 0.84 \\
\hline
\end{tabular}

According to George and Mallery (2003), Cronbach's alpha: $\geq 0.9$ - Excellent, $\geq 0.8$ - Good, $\geq 0.7$ Acceptable, $\geq 0.6$ - Questionable, $>0.5$ - Poor, and $\leq 0.5$ - Unacceptable

Observation checklist

The observation checklist was modified from Harris, Grandgenett and Hofer (2010) and some items were developed by the researcher to fit the context and to make a focus on only ICT tools which are available in Tanzania secondary schools. The observation checklist was reviewed by experienced researchers in education and was administered during microteaching. Both pre and post intervention observations were rated by more than two observers. The inter-rater reliability was calculated by using Krippendorff's alpha (Krippendorff, 2004). The observer were peers who were trained on how to rate by using the observation checklist. The observation checklist used a dual response scale: $1=$ No and $2=$ Yes (see Appendix B). The information comprised in this instrument is summarised in Table 3. 
Table 3

Summary of the observation checklist instrument

\begin{tabular}{|c|c|c|c|}
\hline Construct & Exemplary item & $\begin{array}{l}\text { No. of } \\
\text { items }\end{array}$ & $\begin{array}{l}\text { Krippendor } \\
\text { ff's alpha }\end{array}$ \\
\hline TK & $\begin{array}{l}\text { * Demonstrate ability in the use of learning support tools such } \\
\text { as computer and data projector }\end{array}$ & 3 & 0.694 \\
\hline PK & $\begin{array}{l}\text { *Employs learner centred approaches to engage learners in the } \\
\text { learning process }\end{array}$ & 3 & 0.509 \\
\hline CK & Clearly introduced the topic and learning goals & 3 & 0.667 \\
\hline PCK & Uses teaching approaches that arouse students' creativity & 2 & 0.569 \\
\hline TCK & Uses technology to help students learn difficult concepts & 2 & 0.750 \\
\hline TPK & $\begin{array}{l}\text { *Engage students in technology based learning activities such } \\
\text { as doing assignment on a computer }\end{array}$ & 3 & 0.569 \\
\hline TPCK & $\begin{array}{l}\text { *Engage students in the process of exploring science/math } \\
\text { concepts by using technology }\end{array}$ & 3 & 0.667 \\
\hline
\end{tabular}

* developed by the researcher

The inter-rater reliability for PK, PCK and TPK (Table 3) were below $\alpha \geq 0.667$, which is unacceptable according to Krippendorff (2004). These reliability results inform that, there was lack of agreement among raters on the pedagogy related constructs. However, we accepted this data because they provided information which was useful and relevant for getting a first indication of the ability of pre-service teachers in integrating technology in teaching.

Reflection survey

This instrument aimed to assess the perceived effect of the professional development program on the preservice teachers' development of TPACK and was therefore administered at the end of the professional development program. The reflection survey was developed by the researcher and consisted of two parts. The first part consisted of 15 items with statements which could be scored on a 5-point Likert scale $(1=$ strongly disagree, 2 = disagree, 3 = neutral, 4 = agree, 5 = strongly agree). Examples of the items included in this part of the questionnaire are "I attained sufficient skills of integrating technology in teaching during the training" and "I attained sufficient knowledge about TPACK during microteaching". This part of the reflection survey had a reliability of 0.88 Cronbach's alpha. The second part of the survey included open ended questions in which pre-service teachers' expressed their experience with the professional development program. An example of an open ended question is: "What part of the project was more effective for your learning of TPACK and why?"

\section{Data analysis}

Means and standard deviations were computed of the data from the TPACK survey and the reflection survey. To analyse the difference between pre and post-intervention perceived knowledge and skills of integrating technology in teaching, we used the Wilcoxon signed ranks test (McDonald, 2009) to test the statistical difference between pre and post intervention technology use in teaching. Effect sizes were calculated for TPACK survey results, by using Cohen's $d$ (Cohen, 1988). Cohen (1988) provides the definition of effect size as follows: when $d=0.2$, a small effect size; $d=0.5$, medium effect size, and $d=0.8$, it implies a large effect size.

\section{Results}

\section{Pre-service teachers' perceived TPACK before and after the intervention}

The pre-service teachers' perceived knowledge of integrating technology, pedagogy and content was measured for both pre and post intervention. The pre-intervention results showed that pre-service teachers 
self-rated their TK as neutral with a mean of 3.24, TCK and TPCK had means of approximately 4 whereas PK, CK, TPK and PCK were above 4 (Table 4).

Findings in Table 4 showed a significant increase in the pre-service teachers' perceived TK, TCK and TPCK. The effect sizes for these three variables were between 0.5 and 0.8 Cohen's $d$ which implies medium to large effect sizes. The change in physics, biology and mathematics knowledge, PCK and TPK was not significant. The change in PK was negative, but not significant.

Table 4

Pre and post-intervention pre-service teachers' perceived TPACK

\begin{tabular}{|c|c|c|c|c|c|c|}
\hline & \multicolumn{2}{|r|}{ Pre } & Post & \multirow[b]{2}{*}{$\mathrm{Z}$} & \multirow[b]{2}{*}{ Sig. } & \multirow{2}{*}{$\begin{array}{l}\text { Effect } \\
\text { size } \\
\text { (Cohen's } \\
\text { d) }\end{array}$} \\
\hline & $\mathrm{N}$ & $\mathrm{M}(\mathrm{SD})$ & $\mathrm{M}(\mathrm{SD})$ & & & \\
\hline Technological Knowledge & 22 & $3.24(0.67)$ & $3.66(0.50)$ & -2.033 & 0.042 & 0.71 \\
\hline Pedagogical Knowledge & 22 & $4.38(0.42)$ & $4.33(0.32)$ & -0.375 & 0.708 & 0.13 \\
\hline Content Knowledge (Math) & 10 & $4.61(0.53)$ & $4.66(0.30)$ & -0.577 & 0.564 & 0.12 \\
\hline Content Knowledge (Physics) & 6 & $4.46(0.53)$ & $4.66(0.30)$ & -0.447 & 0.655 & 0.46 \\
\hline Content Knowledge (Biology) & 6 & $4.58(0.47)$ & $4.63(0.41)$ & -0.447 & 0.655 & 0.11 \\
\hline Pedagogical Content Knowledge & 22 & $4.20(0.61)$ & $4.34(0.45)$ & -0.921 & 0.357 & 0.26 \\
\hline Technological Content Knowledge & 22 & $3.98(0.57)$ & $4.27(0.43)$ & -1.981 & 0.048 & 0.57 \\
\hline Technological Pedagogical Knowledge & 22 & $4.03(0.76)$ & $4.35(0.43)$ & -1.639 & 0.101 & 0.51 \\
\hline $\begin{array}{l}\text { Technological Pedagogical Content } \\
\text { Knowledge }\end{array}$ & 22 & $3.85(0.51)$ & $4.17(0.38)$ & -2.299 & 0.022 & 0.71 \\
\hline
\end{tabular}

Likert Scale: 1 = strongly disagree, 2 = disagree, 3 = neutral, 4 = agree, 5 = strongly agree

\section{Observed pre-service teachers' TPACK in teaching before and after the intervention}

Prior to the intervention, pre-service teachers organised themselves into teams of at most six members and designed lessons that integrate technology. There were four teams which participated in the design of technology integrated lessons. Group 1 designed a physics lesson (pendulum), group 2 mathematics (circles), group 3 mathematics (charts) and group 4 biology (fertilisation in plants). These lessons were taught to peers in a microteaching session. Although pre-service teachers had basic knowledge of technology, pedagogy and content, it was noted during the microteaching that, the interplay between technology pedagogy and content was missing.

In both the first (pre-intervention) and second (post-intervention) microteaching, peers and the researcher observed pre-service teachers' practices with technology. A Wilcoxon Signed Rank Test for pre- and postintervention results showed significant changes in technology related components of TPACK, which are TK, TCK, TPK and TPCK (Table 5). 
Table 5

Differences in TPACK of the teams as observed during microteaching: before and after intervention $(N=4)$

\begin{tabular}{|c|c|c|c|c|c|}
\hline & $\begin{array}{c}\text { Pre } \\
\text { M (SD) }\end{array}$ & $\begin{array}{c}\text { Post } \\
\text { M (SD) }\end{array}$ & $\begin{array}{c}\text { Z- } \\
\text { score }\end{array}$ & sig & $\begin{array}{c}\text { Effect } \\
\text { size } \\
\text { (Cohen' } \\
\text { s d) }\end{array}$ \\
\hline Technological Knowledge & $\begin{array}{c}1.24 \\
(0.30)\end{array}$ & $\begin{array}{c}1.69 \\
(0.30)\end{array}$ & -4.69 & $\begin{array}{c}0.00 \\
0\end{array}$ & 1.67 \\
\hline Pedagogical Knowledge & $\begin{array}{c}1.65 \\
(0.43)\end{array}$ & $\begin{array}{c}1.50 \\
(0.38)\end{array}$ & -1.48 & $\begin{array}{c}0.13 \\
9\end{array}$ & 0.37 \\
\hline Content Knowledge & $\begin{array}{c}1.62 \\
(0.29)\end{array}$ & $\begin{array}{c}1.66 \\
(0.29)\end{array}$ & -1.74 & $\begin{array}{c}0.45 \\
8\end{array}$ & 0.14 \\
\hline Pedagogical Content Knowledge & $\begin{array}{c}1.59 \\
(0.33)\end{array}$ & $\begin{array}{c}1.62 \\
(0.28)\end{array}$ & -0.36 & $\begin{array}{c}0.72 \\
0\end{array}$ & 0.10 \\
\hline Technological Content Knowledge & $\begin{array}{l}1.40 \\
(0.38)\end{array}$ & $\begin{array}{c}1.57 \\
(0.36)\end{array}$ & -2.16 & $\begin{array}{c}0.03 \\
1\end{array}$ & 0.54 \\
\hline Technological Pedagogical Knowledge & $\begin{array}{c}1.35 \\
(0.35)\end{array}$ & $\begin{array}{c}1.75 \\
(0.28)\end{array}$ & -4.00 & $\begin{array}{c}0.00 \\
0\end{array}$ & 1.58 \\
\hline $\begin{array}{l}\text { Technological Pedagogical Content } \\
\text { Knowledge }\end{array}$ & $\begin{array}{c}1.39 \\
(0.31)\end{array}$ & $\begin{array}{l}1.67 \\
(0.29)\end{array}$ & -3.16 & $\begin{array}{c}0.00 \\
2\end{array}$ & 0.99 \\
\hline
\end{tabular}

Wilcoxon Signed Rank Test results showed significance differences between pre- and post- intervention results for TK, TCK, TPK, and TPCK, with medium to large effect sizes.

\section{The effect of each activity of the intervention as perceived by the pre-service teachers}

The pre-service teachers considered all activities of the professional development program effective for the development in their understanding of TPACK and their skills in integrating technology in teaching (see also Table 6).

Table 6 Appreciation of each activity in developing TPACK among pre-service teachers $(N=22)$

\begin{tabular}{lcccccc}
\hline & Technology integration & \multicolumn{2}{c}{ Understanding } & \multicolumn{3}{c}{ Relevancy to } \\
& SPills & \multicolumn{2}{c}{ TPACK } & \multicolumn{3}{c}{ teacher education } \\
& 4.39 & 0.45 & 4.00 & 0.38 & 4.46 & 0.39 \\
\hline Training (workshop) & 4.21 & 0.53 & 4.44 & 0.40 & 4.42 & 0.34 \\
Reflection (peer appraisal) & 4.50 & 0.42 & 4.61 & 0.39 & 4.63 & 0.41 \\
Lesson design in teacher design teams & 4.32 & 0.37 & 4.47 & 0.57 & 4.29 & 0.36 \\
Microteaching & & & & & &
\end{tabular}

To determine if any of these activities were more effective than the others analysis of variance (ANOVA) was carried out. Results are presented in Table 7. No significant differences were found between the activities. 
Table 7

ANOVA results for the perceived differences between the learning activities $(\mathrm{N}=22)$

\begin{tabular}{|c|c|c|c|c|c|c|}
\hline & & $\begin{array}{l}\text { Sum of } \\
\text { Squares }\end{array}$ & $\mathrm{df}$ & $\begin{array}{l}\text { Mean } \\
\text { Square } \\
\end{array}$ & $\mathrm{F}$ & Sig. \\
\hline \multirow[t]{3}{*}{$\begin{array}{l}\text { Development of technology } \\
\text { integration skills }\end{array}$} & $\begin{array}{l}\text { Between } \\
\text { Groups }\end{array}$ & 0.273 & 3 & 0.091 & \multirow[t]{3}{*}{0.458} & \multirow[t]{3}{*}{0.714} \\
\hline & $\begin{array}{l}\text { Within } \\
\text { Groups }\end{array}$ & 4.374 & 22 & 0.199 & & \\
\hline & Total & 4.647 & 25 & & & \\
\hline \multirow[t]{3}{*}{$\begin{array}{l}\text { Development of conceptual } \\
\text { understanding of TPACK }\end{array}$} & $\begin{array}{l}\text { Between } \\
\text { Groups }\end{array}$ & 1.419 & 3 & 0.473 & \multirow[t]{3}{*}{2.349} & \multirow[t]{3}{*}{0.100} \\
\hline & $\begin{array}{l}\text { Within } \\
\text { Groups }\end{array}$ & 4.431 & 22 & 0.201 & & \\
\hline & Total & 5.850 & 25 & & & \\
\hline \multirow[t]{3}{*}{ Relevancy to teacher education } & $\begin{array}{l}\text { Between } \\
\text { Groups }\end{array}$ & 0.379 & 3 & 0.126 & \multirow[t]{3}{*}{0.880} & \multirow[t]{3}{*}{0.466} \\
\hline & $\begin{array}{l}\text { Within } \\
\text { Groups }\end{array}$ & 3.159 & 22 & 0.144 & & \\
\hline & Total & 3.538 & 25 & & & \\
\hline
\end{tabular}

Pre-service teachers also expressed their feeling about the professional development programme through the open ended questions that they were provided simultaneously with the reflection questionnaire. In these questions, pre-service teachers were asked to express their opinions on what they learned from the professional development program. About $86 \%$ of the pre-service teachers reported to have learned how to integrate technology with content and pedagogy, whereas $73 \%$ reported to have learned various technologies that can support students' learning, and 59\% reported to have improved their teaching approaches. "I learned a lot about the constructivist learning approaches and how technology can be integrated in the teaching and learning process" responded one of the pre-service teachers from the biology team.

Others expressed the ways the activities incorporated in the professional development program were useful in developing knowledge and skills of integrating technology in teaching. The majority of the pre-service teachers appreciated the design of the professional development program arguing that it offered them an opportunity to reflect on the actual teaching and lesson design process. For example, one of the respondents from the mathematics team argued that:

During the microteaching I was asked questions by colleagues in a way similar to the actual classroom teaching. This made me to read and work more in the second lesson design, where I had to rehearse the lesson with my team members before going to teach others.

Additionally, pre-service teachers indicated that all activities were good for their understanding of technology integration. However, their ranking of the activities according to their importance differed, with the majority of the pre-service teachers perceiving the collaborative lesson design as most important (68\%), others microteaching (59\%), some the training (workshop) (50\%) and few the reflection (36\%). "To me the microteaching was the most important ... for the first time since I joined this college, I have been able to teach by using a projector and a laptop and acted like I am in a real classroom” reported one of the physics team members. 


\section{Discussion}

The aim of this study was to investigate the effect of the professional development arrangement on the development of knowledge and skills of pre-service teachers that are needed to integrate technology in science and mathematics teaching. The push for this study was the poor technology integration in schools in Tanzania (Hare, 2007, Ottevanger et al, 2007; Vesisenaho, 2007). We assumed beforehand that the poor technology uptake by teachers in schools was a result of the limited preparation on technology integration of pre-service teachers' preparation.

With the TPACK survey significant differences were found between pre- and post intervention results for TK, TCK and TPCK, with medium to large effect sizes, implying that pre-service teachers perceive themselves to have developed in these knowledge domains of the TPACK framework. No significant change was found for TPK, which was unexpected. However the pre-service had already rated themselves fairly high before the intervention, which might explain that they did not realise what the integration of technology and pedagogy implies. The observation results showed that all technology-related components of TPACK had changed significantly with medium to large effect sizes, implying that pre-service teachers showed to have developed TPACK when enacting the use of technology in their science and mathematics lessons. Concerning the nontechnology related domains of the TPACK survey no significant changes were found between pre- and post intervention results, implying that the high perception pre-service teachers had before the intervention about their CK, PK and PCK remained constant. Similarly the observation results did not show a significant change between pre- and post intervention results for these domains. These results suggests that the professional development programme was effective in developing pre-service teachers' technology-related domains of TPACK, but not their content and pedagogical knowledge, which were already rather high at the start of the professional development programme. Similar findings were found in the studies of Alayyar et al. (2012) and Agyei and Voogt (2012).

The professional development program adopted in this study involved a combination of microteaching, training, lesson design and reflection. Findings have shown that all the activities within the professional development program were appreciated by the pre-service teachers for developing technology integration knowledge and skills. No significant differences were found between preferences of one activity over the other. However, the open-ended questions showed that the majority of pre-service teachers very much appreciated collaborative lesson design for their learning of technology integration in science and mathematics teaching. This finding is in compliance with the findings from Agyei and Voogt (2012) and Alayyar et al. (2012) which revealed that, when pre-service teachers design a lesson with peers they get an opportunity to reflect on the concept of TPACK and acquire skills needed to integrate technology in science and mathematics (cf. Tondeur et al., 2012). In teams, pre-service teachers get an opportunity to share their knowledge and skills; some are good in content, others in pedagogy and others in technology. Collaboration in design teams encourages a give and receive system, or in other words, if you give what you know (information, experiences, etc.), you will receive what you do not know.

Microteaching was acknowledged for providing the opportunity for pre-service teachers to experience technology integration in a context similar to the real classroom (cf. Kilic, 2010, Tondeur et al., 2012). In microteaching, teachers got acquainted to methods in overcoming challenges of technology integration in real classroom settings, and developed confidence to navigate around and between technology, pedagogy and content. By doing this they moved from the knowledge of technology, pedagogy and content as individual disciplines to integrated knowledge, understood as TPACK (Koehler \& Mishra, 2008). This helped them to implement the ideas from the reflection and the design teams, and also to experience from one another the way technology can be integrated.

We consider the professional development program used in this study, effective for the development of technology integration competencies, because it provides pre-service teachers with hands-on experience in designing and teaching technology integrated lessons. Pre-service teachers were subjected to two important innovations. First the opportunity to experience the design and teaching of the technology integrated lesson in 
a way similar to the actual classroom teaching. This can develop pre-service teachers' practical experiences with technology and build confidence in pre-service teachers (Peker, 2009). Second is the opportunity to think about technology integration by using TPACK as a conceptual framework. By developing the conceptual understanding of TPACK pre-service teachers can effectively integrate technology with science or mathematics and pedagogy (cf. Tondeur et al., 2012). The opportunity to practice the integration of technology in a way similar to real classroom, work in teams and reflect on their practices is missing in most of the teacher training colleges in Tanzania. Our study demonstrated the need for authentic learning activities to train pre-service teachers to adequately and effectively integrate technology in their future classrooms. This study was a relatively small study with a limited number of participants. It can be considered a proof of concept study (Borko, 2004). Borko (2004) argues that a next step is to determine whether the professional development programme can be enacted beyond the current setting, while keeping its critical features.

\section{Conclusion}

Given the findings of this study we hereby draw two conclusions: (1) pre-service teachers who participated in the professional development designed in this study had sufficient knowledge of pedagogy, content and pedagogical content knowledge but limited knowledge of technology related components of TPACK as revealed in self-perception and observation data; (2) training, microteaching, reflection and lesson design were perceived to have almost equal impact on the development of pre-service teachers' knowledge and skills of integrating technology in science and mathematics teaching.

In this study we analysed and argued that the low uptake of technology in schools in Tanzania, as was observed by Hare (2007) and Ottevanger et al. (2007), is a result of poor teachers' understanding of technology integration in teaching, lack of practical experience with technology, and lack of collaboration among teachers (cf. Agyei \& Voogt, 2012; Alayyar et al. (2012). The concept of TPACK (which is a relatively new framework in Tanzania) was relevant for preparing pre-service teachers to use technology. We therefore recommend applying and evaluating the current approach for the professional development to develop TPACK for in-service teachers, so that they can also learn to integrate technology by designing and practicing technologically enhanced lessons for their own classrooms.

\section{References}

Agyei, D., \& Voogt, J. (2012). Developing technological pedagogical content knowledge in pre-service mathematics teachers, through teacher design teams. Australasian Journal of Educational Technology, 28(4), 547-564.

Alayyar, G. (2011). Developing pre-service teacher competencies for ict integration through design teams. Doctoral dissertation. Enschede: University of Twente.

Alayyar, G., Fisser, P., \& Voogt, J. (2012). Developing technological pedagogical content knowledge in preservice science teachers: The potential of blended support for learning. Australasian Journal of Educational Technology, 28(8), 1298-1316.

Angeli, C., \& Valanides, N. (2009) Epistemological and methodological issues for the conceptualization, development, and assessment of ICT-TPCK: Advances in technological pedagogical content knowledge (TPCK). Computers \& Education, 52, 154-168. http://dx.doi.org/10.1016/j.compedu.2008.07.006

Borko, H. (2004). Professional development and teacher learning: mapping the terrain. Educational Researcher, 33, 3-15. http://dx.doi.org/10.3102/0013189X033008003

Cohen, J. (1988). Statistical power analysis for the behavioral sciences (2nd ed.). Hillsdale, NJ: Lawrence Erlbaum Associates.

Dudink, G., \& Berge, Z. (2006). Balancing top-down, bottom-up, and peer-to-peer approaches to sustaining distance training. Turkish Online Journal of Distance Education, 7(3), 144-153.

Fullan, M. (2007). The new meaning of education change (4th ed.). London: Teachers College Press.

Hare, H. (2007). Survey of ICT in education in Tanzania. In G. Farrell, S. Isaacs, \& M. Trucano (Eds.). Survey of ICT and education in Africa (Vol. 2: 53 country reports. Washington, DC: infoDev / World Bank. 
Harris, J., Grandgenett, N., \& Hofer, M. (2010). Testing a TPACK-based technology integration assessment rubric. Retrieved from http://ncsuced1to1.wikispaces.com/file/view/Harris10.pdf.

Jimoyiannis, A. (2010). Designing and implementing an integrated technological pedagogical science knowledge framework for science teachers' professional development. Computers \& Education, 55(3), 1259-1269. http://dx.doi.org/10.1016/j.compedu.2010.05.022

Kafyulilo, A., Fisser, P. \& Voogt, J. (2014). Determinants of the sustainability of teacher design teams as a professional development arrangement for developing technology integration knowledge and skills. In M. Searson \& M. Ochoa (Eds.). Proceedings of Society for Information Technology \& Teacher Education International Conference 2014 (pp. 2130-2136). Chesapeake, VA: AACE.

Kilic, A. (2010). Learner-centered microteaching in teacher education. International Journal of Instruction, 3(1), 77-100.

Koehler, M. J., \& Mishra, P. (2008). Introducing TPCK. In AACTE Committee on Innovation and Technology (Ed.), The handbook of technological pedagogical content knowledge (TPCK) for educators (pp. 3-29). New York, NY: Routledge.

Koehler, M.J., Mishra, P., \& Yahya, K. (2007). Tracing the development of teacher knowledge in a design seminar: Integrating content, pedagogy, \& technology. Computers and Education, 49(3), 740-762. http://dx.doi.org/10.1016/j.compedu.2005.11.012

Koh, J. H. L., Chai, C. S., \& Tay, L. Y. (2014). TPACK-in-action: Unpacking the contextual influences of teachers' construction of technological pedagogical content knowledge (TPACK). Computers \& Education 78, 20-29. http://dx.doi.org/10.1016/j.compedu.2014.04.022

Krippendorff, K. (2004). Reliability in content analysis: Some common misconceptions and recommendations. Human Communication Research, 30(3), 411-433. http://dx.doi.org/10.1111/j.14682958.2004.tb00738.x

Law, N., Yuen, J., \& Lee, Y. (2014). Supporting teacher learning for pedagogical innovation through collaborative co-design: Issues and challenges. In: J. L. Polman, E. A. Kyza, D. K. O'Neill, I. Tabak, W. R. Penuel, A. S. Jurow, K. O'Connor, T. Lee, \& L. D'Amico (Eds.), Proceedings of the 11th International Conference of the Learning Sciences (pp. 777-784). Boulder, Colorado.

Lee M. H., \& Tsai C. C. (2010) Exploring teachers' perceived self efficacy and technological pedagogical content knowledge with respect to educational use of the World Wide Web. Instructional Science, 38, 121. http://dx.doi.org/10.1007/s11251-008-9075-4

McDonald, J. H. (2009). Handbook of biological statistics (2nd ed.). Baltimore: Sparky House Publishing.

Mishra, P., \& Koehler, M.J. (2006). Technological Pedagogical Content Knowledge: A framework for integrating technology in teacher knowledge. Teachers College Record, 108(6), 1017-1054. http://dx.doi.org/10.1111/j.1467-9620.2006.00684.x

O-saki K. M. (2007). Science and mathematics teacher preparation in Tanzania: Lessons from teacher improvement projects in Tanzania: 1965-2006. NUE Journal of International Educational Cooperation, 2, 51-64.

Ottevanger, W., van den Akker, J., \& de Feiter, L. (2007). Developing science, mathematics, and ICT education in sub-Saharan Africa: Patterns and promising practices. World Bank Working Paper No.101. Washington D.C: The World Bank.

Peker, M. (2009). The use of expanded microteaching for reducing pre-service teachers' teaching anxiety about mathematics. Scientific Research and Essay, 4(9), 872-880.

Schmidt, D. A., Baran, E., Thompson, A. S., Mishra, P., Koehler, M. J., \& Shin, T. S. (2009). Technological pedagogical content knowledge (TPACK): The development and validation of an assessment instrument for preservice teachers. Journal of Research on Technology in Education, 42, 123-149. http://dx.doi.org/10.1080/15391523.2009.10782544

Swarts, P., \& Wachira, E. M. (2010). Tanzania: ICT in education situational analysis. Dar es salaam: Ministry of Education and Vocational Training.

Thompson, A. D., \& Mishra, P. (2007-2008). Breaking News: TPCK becomes TPACK! Journal of Computing in Teacher Education. 24(2), 38-39.

Tilya, F. (2008). IT and educational policy in the sub-Saharan African region. In J. Voogt \& G. Knezek (Eds.), International handbook of information technology in primary and secondary education, (pp. 11451159). New York: Springer. http://dx.doi.org/10.1007/978-0-387-73315-9_73 
Tondeur, J., Pareja Roblin, N., Braak, J. van, Fisser, P., \& Voogt, J. (2012). Technological pedagogical content knowledge in teacher education: in search of a new curriculum. Educational Studies, DOI:10.1080/03055698.2012.713548.

United Republic of Tanzania (2003). National Information and Communication Technology policy. Dar es salaam: Ministry of Education and Vocational Training.

United Republic of Tanzania (2007). Information and Communication Technology policy for basic education. Dar es salaam: Ministry of Education and Vocational Training.

United Republic of Tanzania (2008). The education development in the United Republic of Tanzania. National Report. Dar es salaam: Ministry of Education and Vocational Training.

United Republic of Tanzania (2009). A framework for ICT use in teacher professional development in Tanzania. Dar es Salaam: Ministry of Education and Vocational Training.

Vesisenaho, M. (2007). Developing university-level introductory ICT education in Tanzania: A contextualized approach. (Unpublished doctoral dissertation). Joensuu: University of Joensuu.

Voogt, J., Fisser, P., Pareja Roblin, N., Tondeur, J., \& van Braak, J. (2013). Technological pedagogical content knowledge - A review of the literature. Journal of Computer Assisted Learning, 29(2), 109-121. http://dx.doi.org/10.1111/j.1365-2729.2012.00487.x

Voogt, J., Westbroek, H., Handelzalts, A., Walraven, A., Mckenney, S., Pieters, J., \& De Vries, B. (2011). Teacher learning in collaborative curriculum design. Teaching and Teacher Education, 27,8, 1235-1244. http://dx.doi.org/10.1016/j.tate.2011.07.003

Corresponding author: Petra Fisser, p.fisser@slo.nl

Australasian Journal of Educational Technology (c) 2015.

Please cite as: Kafyulilo, A., Fisser, P., Pieters, J. \& Voogt, J. (2015). ICT Use in Science and Mathematics Teacher Education in Tanzania: Developing Technological Pedagogical Content Knowledge. Australasian Journal of Educational Technology, 31(4), 381-399. 


\section{Appendix A}

\section{Pre-service teachers' TPACK survey}

This questionnaire is meant to collect information about your knowledge and skills of integrating technology in science and teaching. The information provided in this questionnaire will be used for reference only. All information will be treated with high confidentiality.

\section{A. Personal information}

1. Program of study:

2. Gender:

3. Your age:

4. Do you have teaching experiences? Yes/No

a. If yes, for how long?

5. What school subjects are you trained to teach? Circle all subjects you will teach
a. Mathematics
b. Physics
c. Chemistry
d. Biology

6. What educational level do you expect to teach after graduation?
a. Primary school
b. Secondary school (O-level)
c. Secondary school (A-level)
d. Teachers' college

\section{B. Technology integration knowledge and skills}

\begin{tabular}{|l|l|l|l|l|l|}
\hline How do you rate your technological Knowledge & $\begin{array}{c}\text { Strongly } \\
\text { disagree }\end{array}$ & Disagree & $\begin{array}{c}\text { Not } \\
\text { sure }\end{array}$ & Agree & $\begin{array}{c}\text { Strongly } \\
\text { agree }\end{array}$ \\
\hline 1 & I can use technology without problems & & & & \\
\hline 2 & I know how to solve my own technical problems & & & & \\
\hline 3 & I can learn technology easily & & & \\
\hline 4 & I have the technical skills, I need to use technology & & & & \\
\hline 5 & $\begin{array}{l}\text { I have sufficient opportunity to work with different } \\
\text { technologies at the college }\end{array}$ & & & & \\
\hline 6 & I keep up with my important new technology & & & \\
\hline 7 & I know about a lot of different technology & & & \\
\hline How can you rate your pedagogical knowledge & & & & \\
\hline 8 & $\begin{array}{l}\text { I know how to assess students performance in the } \\
\text { classroom }\end{array}$ & & & & \\
\hline 9 & $\begin{array}{l}\text { I can adapt my teaching based on what students } \\
\text { currently understand or do not understand }\end{array}$ & & & & \\
\hline 10 & I can adapt my teaching style to different learners & & & & \\
\hline 11 & I can assess student learning in multiple ways & & & & \\
\hline 12 & $\begin{array}{l}\text { I can use a wide range of teaching approach in a } \\
\text { classroom setting }\end{array}$ & & & & \\
\hline 13 & I am familiar with common student understanding & & & & \\
\hline
\end{tabular}




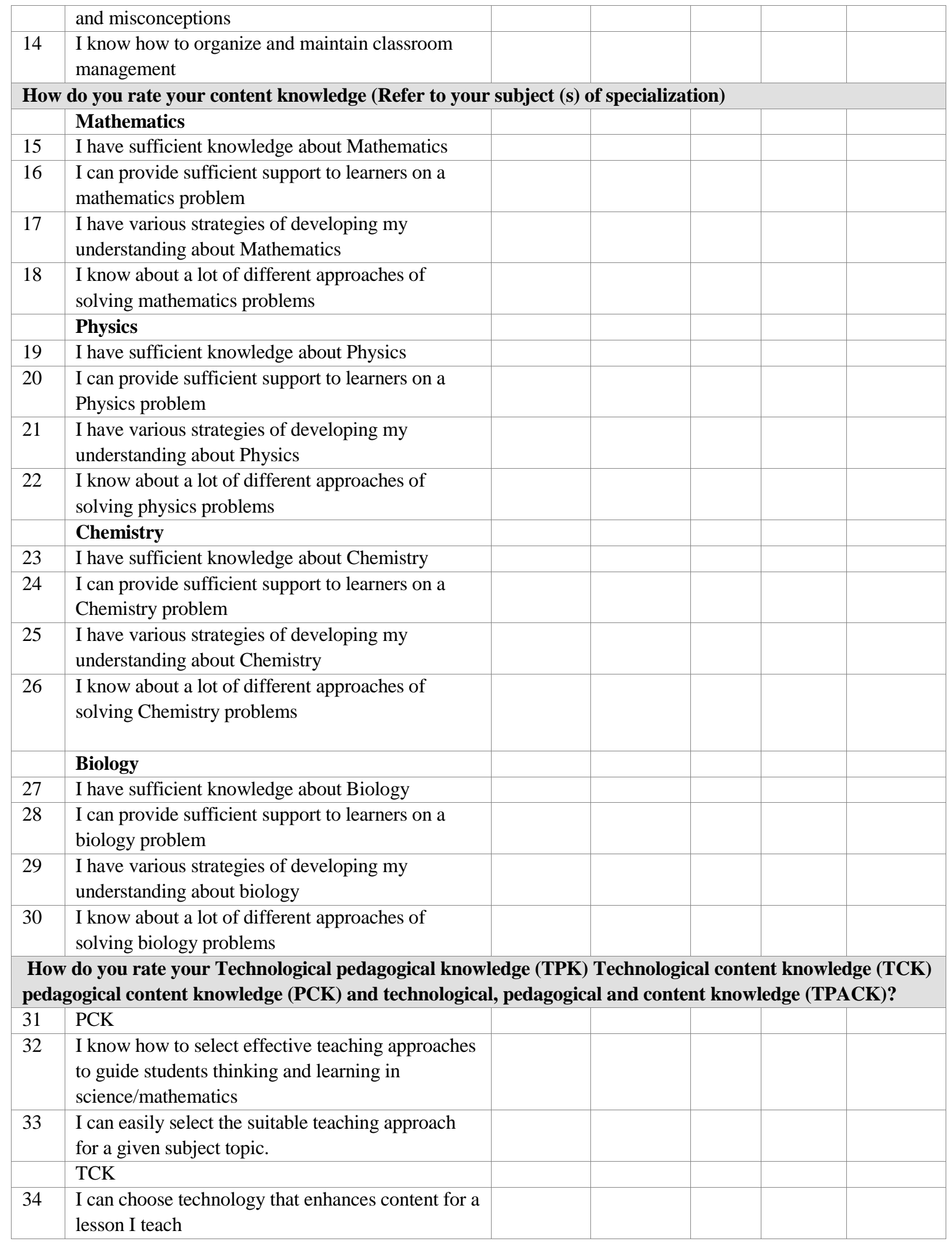




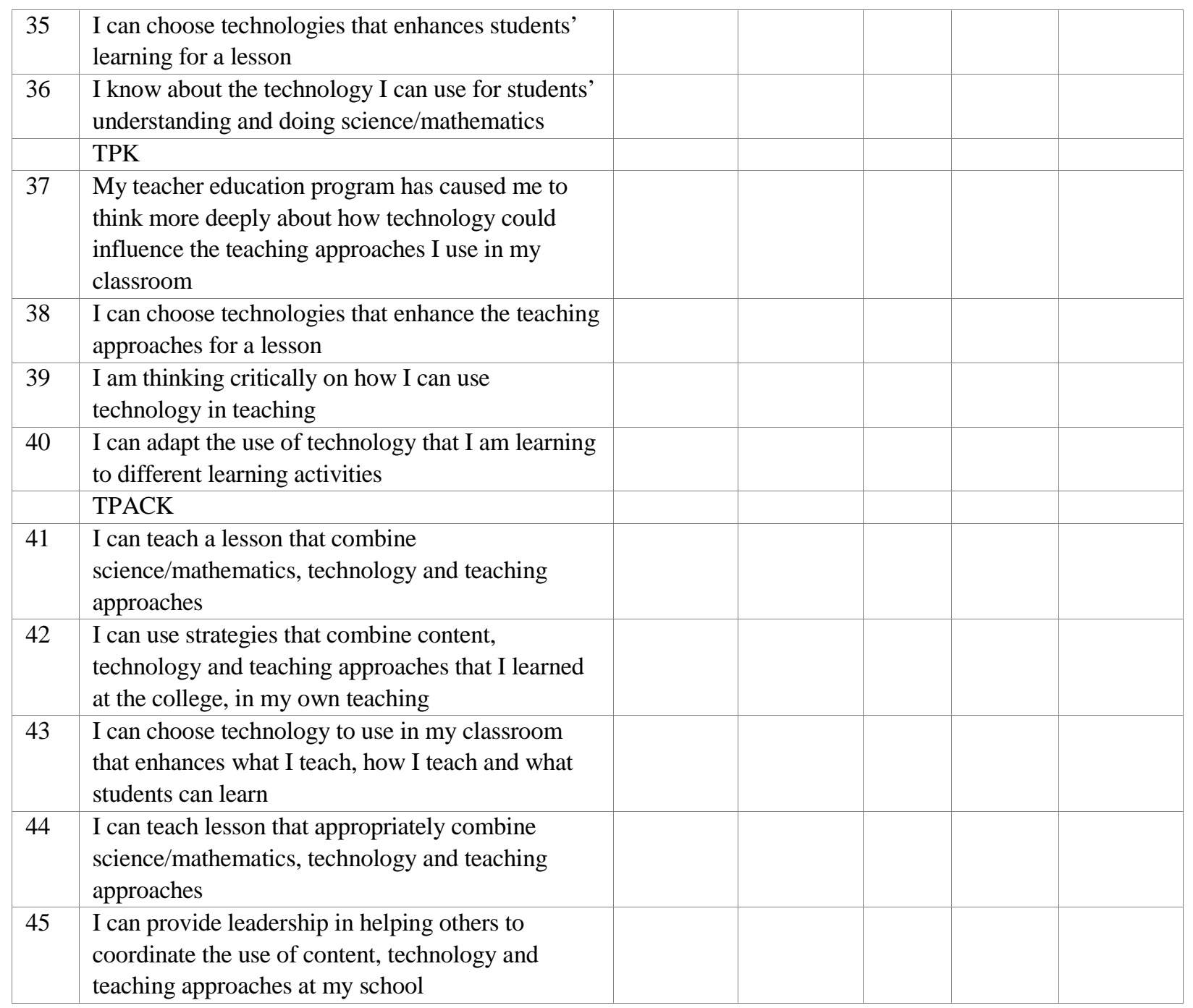




\section{Appendix B}

\section{TPACK observation checklist}

The observation checklist was used to assess the pre-service teachers' implementation of the designed technology integrated lessons during microteaching.

\begin{tabular}{|c|c|c|c|}
\hline & Subject matter knowledge & Yes & No \\
\hline 1. & Clearly introduced the topic and learning goals & & \\
\hline 2. & Has sufficient knowledge of science/mathematics, & & \\
\hline 3. & $\begin{array}{l}\text { Uses appropriate materials in relation to a given science/Mathematics topic being } \\
\text { taught }\end{array}$ & & \\
\hline \multicolumn{4}{|c|}{ Technological knowledge } \\
\hline 4. & $\begin{array}{l}\text { Demonstrate ability in the use of learning support tools such as computer and data } \\
\text { projector }\end{array}$ & & \\
\hline 5. & $\begin{array}{l}\text { Demonstrate ability in technology systems and the transfer of the knowledge to new } \\
\text { situations. }\end{array}$ & & \\
\hline 6. & $\begin{array}{l}\text { Skills of using communication tools such as email, chat, forums etc to facilitate } \\
\text { learning }\end{array}$ & & \\
\hline \multicolumn{4}{|c|}{ Pedagogical knowledge } \\
\hline 7. & $\begin{array}{l}\text { Engage students in exploring real-world issues and solving authentic problems using } \\
\text { digital tools and resources. }\end{array}$ & & \\
\hline 8. & Employs learner centered approaches to engage learners in the learning process & & \\
\hline 9. & $\begin{array}{l}\text { Address the diverse needs of all learners by using learner-centered strategies providing } \\
\text { equitable access to appropriate digital tools and resources. }\end{array}$ & & \\
\hline \multicolumn{4}{|c|}{ Technological pedagogical knowledge } \\
\hline 10. & Engage students in technology based inquiry learning activities & & \\
\hline 11. & Use technology to help students to collaborate across multiple contexts & & \\
\hline 12. & Teach and model the use of appropriate pedagogies and technologies for learning & & \\
\hline \multicolumn{4}{|c|}{ Technological Content knowledge } \\
\hline 13. & Uses technology to help students learn difficult concepts & & \\
\hline 14. & $\begin{array}{l}\text { Design relevant learning experiences that incorporate digital tools and resources to } \\
\text { promote student learning and creativity. }\end{array}$ & & \\
\hline \multicolumn{2}{|r|}{ Pedagogical content knowledge } & & \\
\hline 15. & Uses teaching approaches that arouse students' creativity & & \\
\hline 16. & $\begin{array}{l}\text { Apply teaching approaches which gives more authority to students in solving } \\
\text { science/mathematics problem }\end{array}$ & & \\
\hline
\end{tabular}




\section{Technological Pedagogical and Content Knowledge}

17. $\quad$ Proper choice of technology in relation to content and pedagogy

18. Engage students in the process of exploring science/math concepts by using technology

19. Promote students' reflection using collaborative tools to reveal and clarify students' conceptual understanding, thinking and creativity 